\title{
Moderasi Perbedaan Opini terhadap Faktor-Faktor Kinerja Harga Saham pada Perusahaan Sektor Pariwisata Saat Pandemi Covid-19
}

\author{
I Gst Ayu Eka Damayanthi ${ }^{1}$ \\ Fakultas Ekonomi dan Bisnis \\ Universitas Udayana, Indonesia
}

\author{
Ni Ketut Lely Aryani Merkusiwati ${ }^{2}$ \\ Fakultas Ekonomi dan Bisnis \\ Universitas Udayana, Indonesia
}

\begin{abstract}
Surel : ekadamayanthi@unud.ac.id
ABSTRAK

Perekonomian yang tidak menentu dan cenderung krisis berdampak pada pasar modal di Indonesia. Penelitian ini bertujuan untuk menganalisis pengaruh profitabiltas, leverage, likuiditas dan perbedaan opini terhadap kinerja harga saham serta peran perbedaan opini inestor dalam memoderasi pengaruh profitabilitas, leverage, dan likuiditas terhadap kinerja harga saham. Populasi dalam penelitian ini adalah Perusahaan Sektor Pariwisata yang terdaftar di Bursa Efek Indonesia. Jumlah observasi penelitian 136 observasi. Analisis data menggunakan analisis regresi moderasi. Hasil penelitian profitabilitas dan leverage berpengaruh positif pada return saham. Leverage yang tidak berpengaruh signifikan pada return saham. Hasil penelitian ini juga tidak membuktikan bahwa perbedaan opini investor memoderasi pengaruh profitabilitas, leverage, likuiditas terhadap kinerja harga saham kemungkinan dikarenakan perusahaan sektor pariwisata tidak terlalu disukai oleh investor sehingga harga saham tidak banyak bergerak saat kondisi pandemi Covid19.
\end{abstract}

Kata Kunci: Profitabilitas; Leverage; Likuiditas; Kinerja Harga Saham.

Moderation of Opinion Differences on Stock Price Performance Factors in Tourism Sector Companies During the Covid-19 Pandemic

\begin{abstract}
An uncertain and crisis-prone economy has an impact on the capital market in Indonesia. This study aims to analyze the effect of profitability, leverage, liquidity and differences of opinion on stock price performance and the role of investors' differences of opinion in moderating the effect of profitability, leverage, and liquidity on stock price performance. The population in this study is the tourism sector companies listed on the Indonesia Stock Exchange. The number of research observations was 136 observations. Data analysis used moderated regression analysis. The results of the study of profitability and leverage have a positive effect on stock returns. Leverage which has no significant effect on stock returns. The results of this study also do not prove that differences in investor opinions moderate the effect of profitability, leverage, liquidity on stock price performance, possibly because tourism sector companies are not very favored by investors so that stock prices do not move much during the Covid-19 pandemic.

Keywords: Profitability; Leverage; Liquidity; Stock Price Performance.
\end{abstract}

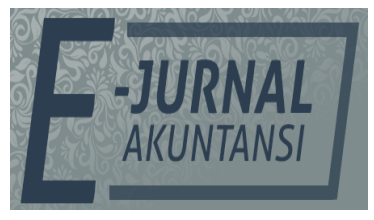

e-ISSN 2302-8556

Vol. 31 No. 10

Denpasar, Oktober 2021

Hal. 2663-2676

DOI:

10.24843/EJA.2021.v31.i10.p20

PENGUTIPAN:

Damayanthi, I.G.A.E., \& Merkusiwati, N.K.L.A. (2021).

Moderasi Perbedaan Opini terhadap Faktor-Faktor

Kinerja Harga Saham pada Perusahaan Sektor Pariwisata Saat Pandemi Covid-19. EJurnal Akuntansi, 31(10), 2663-

2676

RIWAYAT ARTIKEL: Artikel Masuk: 20 September 2021 Artikel Diterima: 27 Oktober 2021

Artikel dapat diakses : https://ojs.unud.ac.id/index.php/Akuntansi/index 


\section{PENDAHULUAN}

Investor menginvestasikan dananya ke suatu perusahaan yaitu untuk memperoleh pendapatan atau tingkat kembalian investasi (return) baik berupa pendapatan dividen (dividen yield) maupun pendapatan dari selisih harga jual saham terhadap harga belinya (capital gain) (Brigham \& Houston, 2010:125). Return saham secara umum dapat dipengaruhi oleh faktor fundamental dan teknikal. Wabah Covid-19 membuat perekonomian dunia menjadi terpuruk, peningkatan terjadi di di negara yang perekonomiannya terdampak di seluruh dunia seperti Amerika, Spanyol dan Italia membuat situasi ekonomi dunia semakin memburuk. International Monetary Fund (IMF) memproyeksikan ekonomi global minus di angka 3 persen, beberapa lembaga memprediksikan perlemahan ekonomi seperti halnya IMF (Indrawati, 2020).

Perekonomian yang tidak menentu dan cenderung krisis berdampak pada pasar modal di Indonesia. Para regulator berupaya keras dengan mengeluarkan berbagai kebijakan seperti kebijakan penghentian perdagangan (trading halt) agar mampu menahan keruntuhan Indeks Harga Saham Gabungan (IHSG). Fenomena ini sangat jarang terjadi didunia. Kondisi ekonomi yang tidak stabil, pertumbuhan ekonomi yang rendah, ketidakpastian ekonomi yang tinggi sangat mempengaruhi harga saham di Bursa Efek di seluruh dunia termasuk di Indonesia. Kondisi ketidakpastian ini mengakibatkan investor memiliki estimasi penilaian yang berbeda terhadap kinerja saham. Investor yang optimis akan menilai saham lebih tinggi dari pada nilai wajarnya. Sektor yang paling berdampak pada pandemi Covid-19 adalah sektor pariwisata. Berkurangnya kunjungan wisata ke Indonesia dan ke semua negara menyebabkan sektor pariwisata merasakan dampak yang sangat besar, sehingga penelitian meneliti kinerja saham perusahaan sektor pariwisata di Bursa Efek Indonesia (Sugianto, 2020).

Penilaian kinerja harga saham yang dapat dilakukan dengan menganalisa faktor-faktor yang mempengaruhinya antara lain rasio keuangan. Rasio-rasio keuangan yang diteliti adalah rasio profitabilitas, leverage dan likuiditas. Beberapa bukti empiris menjelaskan hasil yang tidak konsisten mengenai pengaruh profitabilitas, leverage, dan likuiditas terhadap kinerja harga saham (Khan, et al., 2013), (Fahmi et al., 2019), (Araújo \& Machado, 2018), (Obeidat, 2016), (Acheampong, et al., 2014), (Allozi \& Obeidat, 2016), (Nurhakim, et al., 2016), (Wong, et al., (2015), (Khan, 2017), dan (Musa \& Obeidat, 2016). Penelitian ini ingin menguji kembali pengaruh profitabilitas, leverage dan likuiditas terhadap kinerja harga saham pada saat pandemi covid di perusahaan sektor pariwisata.

Hasil penelitian yang tidak konsisten memberikan gambaran bahwa kemungkinan ada faktor lain yang mempengaruhi harga saham. Miller (1977) menjelaskan prilaku investor dalam menghadapi ketidakpastian PUP. Model Miller ini mencoba melepaskan salah satu asumsi Capital Asset Pricing Model (CAPM) yaitu investor memiliki ekspektasi return yang sama. Asumsi ini tidak mungkin terealisasi apabila investor menghadapi kondisi ketidapastian yang tinggi akibatnya investor memiliki estimasi penilaian yang berbeda atas saham. Hal ini yang menimbulkan perbedaan opini investor terhadap nilai saham.

Perbedaan opini mempengaruhi keyakinan investor terhadap pengaruh rasio keuangan terhadap nilai saham disebabkan kondisi ketidakpastian. Rasio keuangan tidak cukup memberikan keyakinan investor terhadap harga saham. 
Beberapa data prospektus juga dapat menjelaskan kinerja harga saham. Hipotesis perbedaan opini Miller (1977) didukung oleh penelitian Bhabra \& Pettway, (2003) penurunan return dapat dijelaskan dengan ketidakpastian yang berdampak pada perbedaan opini investor.

Ketidakpastian, perbedaan opini, dan risiko berjalan bersama-sama. Risiko berhubungan positif dengan perbedaan opini investor yang optimis dan pesimis (Miller, 1977). Fenomena Covid-19 dapat menjelaskan penurunan kinerja harga saham pada awal pandemi. Kinerja harga saham yang berfluktuasi menunjukan ketidakpastian dan perbedaan opini investor (Houge et al., (2001), (Gao \& Zhong, 2006), dan (Jewarthowski \& Lizinska, 2012).

Hasil penelitian yang tidak konsisten yang berhubungan dengan pengaruh rasio keuangan terhadap kinerja harga saham maka diduga terjadi perbedaan opini investor yang dapat memperlemah atau memperkuat pengaruh rasio keuangan terhadap kinerja harga saham. Hal ini disebabkan adanya faktor ketidakpastian dan risiko berinvestasi pada pasar modal saat pandemi Covid-19.

Penelitian yang menggunakan perbedaan opini investor ini masih sangat jarang sehingga ini merupakan perbedaan yang mendasar dari penelitian ini dengan penelitian sebelumnya. Berdasarkan fenomena dan riset gap maka penelitian memiliki beberapa pertanyaan penelitian antara lain apakah profitabalitas, leverage, likuiditas dan perbedaan opini investor berpengaruh terhadap kinerja harga saham pada perusahaan sektor pariwisata. Apakah perbedaan opini memoderasi pengaruh profitabilitas, leverage, likuiditas terhadap kinerja harga saham pada perusahaan sektor pariwisata.

Penelitian ini menggunakan teori sinyal yang menekankan pada pandangan para pemegang saham terkait dengan peluang perusahaan menjaga nilai perusahaan di masa depan (Brigham \& Houston, 2014:184). Teori sinyal disampaikan oleh manajemen perusahaan kepada pemegang saham. Teori sinyal dapat diartikan sebagai suatu isyarat yang dilakukan oleh perusahaan kepada pihak eksternal. Isyarat tersebut dapat berupa sinyal positif maupun negatif, informasi yang dikirimkan perusahaan kepada publik akan dievaluasi dan direspon oleh pasar, dari hal tersebut akan muncul respon atau sikap investor sebagai tanggapan atas sinyal yang diberikan perusahaan (Ghozali, 2020). Model yang paling sering digunakan adalah berfokus pada dua individu-prinsipal (atasan) dan agen (bawahan) dilihat dari perspektif perilaku dan struktur (Jensen \& Meckling, 1976). Prinsipal akan membuat struktur mekanisme yang mengawasi agen agar supaya menahan prilaku oportunistik dan mengikuti kehendak dari prinsipal (Jensen \& Fama, 1983), dan (Ghozali, 2020). Penelitian ini menguji informasi rasio keuangan terhadap harga saham. Kandungan rasio keuangan dan non keuangan serta opini investor merupakan sinyal kepada investor sehingga direspon oleh pasar melalui harga sahamnya. Rasio keuangan yang digunakan adalah rasio profitabilitas, leverage dan likuiditas.

Rasio profitabilitas mengacu pada kinerja keuangan perusahaan dalam menghasilkan laba, apabila laba meningkat maka hal ini akan menunjukkan daya tarik bagi investor dan calon investor dalam menanamkan modalnya ke perusahaan. Jika permintaan saham meningkat maka harga saham akan cenderung meningkat, hal ini akan berakibat pada naiknya return saham. Perusahaan yang menghasilkan keuntungan mencerminkan kinerja suatu 
perusahaan baik sehingga harga saham dan return saham meningkat (Raningsih \& Putra, 2015). Hasil penelitian Mariani et al., (2016), Raningsih \& Putra (2015), Saleh (2015), Har \& Afif (2015), dan Khan et al., (2013) menunjukkan bahwa profitabilitas berpengaruh positif dan signifikan terhadap return saham. Penelitian dari Fahmi et al., (2019) mengindikasi bahwa profitabilitas berpengaruh signifikan baik secara simultan dan secara parsial terhadap return saham. Rasio keuangan profitabilitas berisi kandungan informasi yang memberikan sinyal kepada investor yang akan mempengaruhi kinerja harga saham. Maka hipotesis penelitian ini adalah sebagai berikut.

$\mathrm{H}_{1}$ : Profitabilitas berpengaruh positif terhadap kinerja harga saham.

Rasio leverage menunjukkan kemampuan perusahaan untuk memenuhi segala kewajiban finansialnya baik itu memenuhi kewajiban jangka panjang maupun jangka pendeknya. Leverage akan memberikan sinyal sesuai dengan teori sinyal kepada investor atau stakeholder berhubungan dengan kemampuan perusahaan dalam kemampuan membayar utang. Semakin tinggi leverage maka semakin tinggi kepercayaan investor terhadap perusahaan sehingga meningkatkan harga saham perusahaan. Hasil penelitian dari Budiharjo (2018) leverage (DER) berpengaruh positif dan tidak signifikan terhadap return saham. Hasil penelitian Mariani et al. (2016), Raningsih \&Putra (2015), dan Abdullah et al. (2015) menunjukkan leverage berpengaruh positif dan signifikan terhadap return saham. Berbeda dengan penelitian yang dilakukan Acheampong et al. (2014), Allozi \& Obeidat (2016), dan menunjukkan bahwa DER berpengaruh negatif terhadap return saham. Rasio leverage mempunyai kandungan informasi yang akan memberikan sinyal kepada investor melalui kinerja harga saham. Hipotesis penelitian adalah sebagai berikut.

$\mathrm{H}_{2}$ : Leverage berpengaruh positif terhadap kinerja harga saham.

Rasi Likuiditas mengukur kemampuan jangka pendek perusahaan dengan melihat aktiva lancar perusahaan relatif terhadap hutang lancar. Penelitian ini mengacu pada teori sinyal bahwa likuiditas memberikan sinyal kepada pemangku kepentingan untuk mengambil keputusan. Penelitian ini menggunakan current ratio dalam pengukuran likuiditas. Kemampuan perusahaan dalam menjaga kewajiban keuangan jangka pendek menunjuk semakin tingginya tingkat likuiditas perusahaan. (Parwati \& Sudiartha, 2016). Semakin tinggi kemampuan perusahaan dalam memenuhi kewajiban jangka akan meningkatkan kinerja harga saham perusahaan dilihat dari peningkatan harga saham. Hipotesis yang diajukan adalah sebagai berikut.

$\mathrm{H}_{3}$ : Likuiditas berpengaruh positif terhadap kinerja harga saham.

Pengujian teori Miller (1977) telah dilakukan oleh Houge et al., (2001), Gao \& Zhong (2006), dan Jewarthowski \& Lizinska (2012). Houge et al., (2001), dan Gao \& Zhong (2006) membuktikan secara empiris pengaruh negatif dari perbedaan opini investor terhadap kinerja harga saham jangka panjang. Hal ini berarti semakin tinggi perbedaan opini investor kinerja harga saham jangka panjang semakin rendah. Jewarthowski \& Lizinska (2012) membuktikan secara empiris pengaruh positif perbedaan opini investor terhadap return awal sesuai dengan penemuan Miller (1977). Variabel ini juga mengacu pada teori sinyal karena perbedaan opini investor didasarkan pada kandungan informasi perusahaan. Adanya kontrak dan informasi yang dapat direspon oleh pasar, kemudian 
informasi tersebut memberikan sinyal kepada investor merupakan kaitan antara penelitian ini dengan teori yang digunakan. Berdasarkan teori dan kajian empiris maka hipotesis yang diajukan adalah sebagai berikut.

$\mathrm{H}_{4}$ : Perbedaan opini berpengaruh positif terhadap kinerja harga saham.

Pengujian Miler (1977) menjadi dasar teori perbedaan opini memiliki pengaruh signifikan terhadap kinerja harga saham jangka panjang. Pada penelitian ini perbedaan opini merupakan salah satu faktor yang memperkuat hubungan antara pengaruh rasio keuangan terhadap kinerja harga saham. Ketidakpastian terhadap nilai perusahaan akan menyebabkan perbedaan opini investor (Miller, 1977).

$\mathrm{H}_{5}$ : Perbedaan opini investor memperkuat pengaruh profitabilitas terhadap kinerja harga saham.

Perbedaan opini berpengaruh harga saham, risiko saham, dan fluktuasi harga saham pada awal perdagangan (Miller, 1977). Ketidakpastian informasi bersumber dari kualitas laba perusahaan (Zhang, 2006). Perbedaan opini investor juga dipengaruhi oleh kualitas laporan keuangan. Profitabilitas, leverage, likuiditas juga menjadi pertimbangan investor dalam berinvestasi yang memiliki kemungkinan menjadi objek perbedaan opini investor.

$\mathrm{H}_{6}$ : Perbedaan opini investor memperkuat pengaruh leverage terhadap kinerja harga saham.

Pamucuku (2003) menemukan akrul mempengaruhi perbedaan opni investor setelah dikendalikan dengan keyakinan investor mengenai pertumbuhan, perubahan sentimen, dan batasan penawaran. Berdaasarkan teori dan kajian empiris tersebut maka perbedaan opini investor mungkin merupakan variabel yang dapat memperkuat pengaruh informasi profitabilitas, leverage dan likuiditas terhadap kinerja harga saham pada perusahaan sektor pariwisata di masa Covid19. Maka hipotesis penelitian yang diajukan adalah sebagai berikut.

$\mathrm{H}_{7}$ : Perbedaan opini investor memperkuat pengaruh likuiditas terhadap kinerja harga saham.

\section{METODE PENELITIAN}

Penelitian ini dilakukan pada perusahaan sektor pariwisata yang terdaftar pada Bursa Efek Indonesia tahun 2019-2020. Obyek dalam penelitian ini adalah kinerja harga saham, profitabilitas, leverage, likuiditas dan perbedaan opini investor pada perusahaan Sektor Pariwisata di Bursa Efek Indonesia (BEI) tahun 2019- 2020, karena sektor pariwisata merupakan sektor yang paling berdampak pada pandemi Covid-19.

Populasi dalam penelitian ini adalah 42 Perusahaan Sektor Pariwisata yang terdaftar di Bursa Efek Indonesia. Penelitian ini menggunakan metode non probability sampling dengan teknik purposive sampling, yaitu terdapat kriteriakriteria untuk pengambilan sampel dengan cara sebagai berikut, Perusahaan sub sektor hotel, restoran, dan pariwisata yang masih tercatat (listed) di Bursa Efek Indonesia selama periode 2019-2020 Perusahaan sub sektor hotel, restoran, dan pariwisata yang mempublikasikan laporan keuangan triwulan dan tahunan periode 2019- 2020, Perdagangan saham emiten tidak pernah dihentikan selama lebih dari satu bulan, Perusahaan sub sektor hotel, restoran, dan pariwisata yang tidak mengalami kerugian selama periode penelitian. Berdasarkan data dari Bursa 
efek Indonesia jumlah perusahaan sektor pariwisata adalah 42 perusahaan. Sampel penelitian setelah dikurangi kriteria dan outliner menjadi 17 perusahaan.

Metode pengumpulan data yang dipergunakan dalam penelitian ini adalah studi dokumentasi, yaitu pengumpulan data dengan cara melihat informasi laporan keuangan perusahaan Perusahaan sub sektor hotel, restoran, dan pariwisata periode 2019-2020 yang ada di situs Bursa Efek Indonesia (www.idx.co.id). Kinerja harga saham di proksikan dengan return saham merupakan hasil yang diperoleh dari investasi berupa return saham realisasi. Return saham dapat dinyatakan sebagai berikut (Jogiyanto, 2010:108).

Return Saham $\left(\mathrm{R}_{\mathrm{it}}\right)=\frac{\mathrm{P}_{\mathrm{t}}-\mathrm{P}_{\mathrm{t}-1}}{\mathrm{P}_{\mathrm{t}-1}}$

Keterangan:

$\mathrm{R}_{\mathrm{it}}$ : Tingkat keuntungan saham i pada periode $\mathrm{t}$

$\mathrm{P}_{\mathrm{t}}$ : Harga penutupan saham i pada periode $t$ (periode akhir)

$\mathrm{P}_{\mathrm{t}-1}$ : Harga penutupan saham i pada periode sebelumnya

Menurut Riyanto (2012:35) rasio profitabilitas adalah perbandingan antara laba dengan aktiva atau modal yang menghasilkan laba tersebut, dengan kata lain profitabilitas merupakan kemampuan perusahaan untuk menghasilkan laba. Dalam penelitian ini diukur dengan return on equity yaitu perbandingan antara laba bersih terhadap ekuitas. Return on equity dapat dihitung menggunakan rumus (Sawir, 2010:18-20) sebagai berikut.

Return on Equity $=\frac{\text { Laba Bersih }}{\text { Ekuitas }} \times 100 \%$

Leverage adalah rasio yang menggambarkan kemampuan perusahaan untuk memenuhi segala kewajiban finansialnya seandainya perusahaan pada saat itu dilikuidasi. Dalam penelitian ini diukur dengan debt to equity ratio.

Debt to Equity Ratio $=\frac{\text { Total utang }}{\text { Ekuitas }} \times 100 \%$

Rasio likuiditas adalah kemampuan suatu perusahaan untuk memenuhi kewajiban keuangannya yang harus dipenuhi, atau kemampuan perusahaan memenuhi kewajiban pada saat tagihan sebagai berikut.

Current ratio $=\frac{\text { Aktiva lancar }}{\text { Utang lancar }} \times 100 \%$

Penelitian ini mengukur perbedaan opini investor dengan unexplain volume karena volume perdagangan yang tinggi mengindikasikan perbedaan opini investor (Garfinkel, 2009). Teknik analisis data yang digunakan dalam menguji hipotesis penelitian ini adalah regresi linear berganda dan Uji Moderated Regression Analysis (MRA) Adapun model regresi moderasi (MRA) dalam penelitian ini adalah sebagai berikut.

$Y=\alpha+\beta_{1} X_{1}+\beta_{2} X_{2}+\beta_{3} X_{3}+\beta_{4} X_{4}+\beta_{5} X_{1^{*}} X_{4}+\beta_{6} X_{2} * X 4+\beta_{7} X_{3^{*}} X_{4}+\varepsilon$

Keterangan:

$\begin{array}{ll}\mathrm{Y} & : \text { Kinerja Harga Saham } \\ \mathrm{X}_{1} & : \text { Profitabilitas } \\ \mathrm{X}_{2} & : \text { Leverage } \\ \mathrm{X}_{3} & : \text { Likuiditas } \\ \mathrm{X}_{4} & : \text { Perbedaan opini } \\ \mathrm{a} & : \text { Konstanta } \\ \beta_{1}-\beta_{13} & : \text { Koefisien regresi } \\ \varepsilon & : \text { Error }\end{array}$




\section{HASIL DAN PEMBAHASAN}

Total sampel perusahaan sektor pariwisata setelah data outlier adalah 17 sampel perusahaan. Jumlah sampel periode pengamatan Januari 2019-September 2020 menggunakan laporan triwulanan adalah sebanyak 136 sampel penelitian Penelitian ini menggunakan laporan keuangan triwulan karena melihat perkembangan rutin jangka pendek informasi keuangan dan harga saham perusahaan selama triwulan karena adanya dampak pandemic Covid-19.

\section{Tabel 1. Hasil Seleksi Pemilihan Sampel}

\begin{tabular}{|c|c|c|}
\hline No. & Keterangan & $\begin{array}{c}\text { Akumulasi Jumlah } \\
\text { Perusahaan }\end{array}$ \\
\hline 1 & $\begin{array}{l}\text { Perusahaan sub sektor hotel, restoran, dan } \\
\text { pariwisata yang terdaftar di Bursa Efek Indonesia } \\
\text { pada periode Januari 2019- Desember } 2020 .\end{array}$ & 42 \\
\hline 2 & $\begin{array}{l}\text { Perusahaan sub sektor hotel, restoran dan } \\
\text { pariwisata yang tidak listing secara berturut-turut } \\
\text { di Bursa Efek Indonesia periode Januari 2019- } \\
\text { September } 2020 \text {. }\end{array}$ & (11) \\
\hline 3 & $\begin{array}{l}\text { Perusahaan sub sektor hotel, restoran, dan } \\
\text { pariwisata yang tidak mempublikasikan laporan } \\
\text { keuangan triwulan dan tahunan periode Januari } \\
\text { 2019- September } 2020 \text {. }\end{array}$ & (8) \\
\hline 4 & $\begin{array}{l}\text { Perusahaan sub sektor hotel, restoran, dan } \\
\text { pariwisata yang di suspend selama periode } \\
\text { penelitian } \\
\text { Jumlah Sampel }\end{array}$ & $\begin{array}{l}(3) \\
20\end{array}$ \\
\hline 5 & Data outlier & (3) \\
\hline & $\begin{array}{l}\text { Jumlah sampel perusahaan yang layak diobservasi } \\
\text { Jumlah data observasi }(17 \times 8)\end{array}$ & $\begin{array}{c}17 \\
136\end{array}$ \\
\hline
\end{tabular}

Sumber: Data Penelitian, 2021

Statistik deskriptif berkaitan dengan pengumpulan peringkat data yang menggambarkan karateristik sampel yang digunakan dalam penelitian ini. Hasil analisa statistik deskriptif dapat menjelaskan karakteristik sampel terutama mengenai nilai minimum, nilai maksimum, nilai rata-rata (mean), dan standar deviasi dari masing-masing variabel. Tabel 2, menjelaskan hasil analisis statistik deskriptif penelitian.

Tabel 2. Hasil Analisis Statistik Deskriptif

\begin{tabular}{lrrrrr}
\hline & $\mathrm{N}$ & Minimum & Maximum & Mean & Std. Deviation \\
\hline Return & 136 & $-0,610$ & 0,390 & $-0,053$ & 0,175 \\
Saham & & & & & \\
Profitabilitas & 136 & $-36,170$ & 30,350 & $-0,226$ & 7,005 \\
Leverage & 136 & 13,550 & 189,690 & 76,153 & 42,158 \\
Likuiditas & 136 & 10,250 & 325,450 & 131,494 & 73,125 \\
Perbedaan & 136 & 0,00 & 99,280 & 17,532 & 25,525 \\
Opini & & & & & \\
Valid N & 136 & & & & \\
(listwise) & & & & & \\
\hline
\end{tabular}

Sumber: Data Penelitian, 2021 
Hasil statistik deskriptif adalah nilai terendah variabel return saham diperoleh dari perusahaan Dafam Property Indonesia Tbk (DFAM) pada triwulan 4 tahun 2019 sebesar -0,610. Nilai tertinggi variabel return saham diperoleh dari perusahaan Sarimelati Kencana Tbk (PZZA) pada triwulan 1 tahun 2019 sebesar 0,390. Nilai rata-rata variabel return saham sebesar $-0,0537$ yang berarti rata-rata tingkat return saham pada sampel amatan yang digunakan dalam penelitian ini sejumlah $-0,053$. Nilai standar devasi dari return saham adalah sebesar 0,175 yang menunjukkan bahwa sebesar 0,175 data bervariasi dari rata-rata. Nilai standar deviasi yang lebih tinggi dibandingkan dengan nilai rata-rata membuktikan adanya variasi yang besar antara nilai maksimum dan minimum.

Nilai terendah variabel profitabilitas diperoleh dari Destinasi Tirta Nusantara (PDES) pada triwulan 2 tahun 2020 sebesar -36,165. Nilai tertinggi variabel profitabilitas diperoleh dari perusahaan Indonesian Paradise Property Tbk (INPP) pada triwulan 4 tahun 2019 sebesar 30,350. Nilai rata-rata variabel profitabilitas sebesar -0,226 yang berarti rata-rata tingkat profitabilitas pada sampel amatan yang digunakan dalam penelitian ini sejumlah -0,226. Nilai standar devasi dari profitabilitas adalah sebesar 7,005 yang menunjukkan bahwa sebesar 7,005 data bervariasi dari rata-rata. Nilai standar deviasi yang lebih tinggi dibandingkan dengan nilai rata-rata membuktikan adanya variasi yang besar antara nilai maksimum dan minimum.

Nilai terendah variabel leverage diperoleh dari perusahaan Red Planet Indonesia Tbk (PSKT) pada triwulan 1 tahun 2019 sebesar 13,550. Nilai tertinggi diperoleh dari perusahaan Intikeramik Alamasri Industri Tbk (IKAI) triwulan 2 tahun 2020 sebesar 189,690. Nilai rata-rata leverage sebesar 76,154 yang berarti nilai rata-rata leverage pada sampel amatan yang digunakan dalam penelitian ini sejumlah 76,154. Nilai standar deviasi dari leverage adalah sebesar 42,158 yang menunjukkan bahwa sebesar 42,158 data bervariasi dari rata-rata. Nilai standar deviasi yang lebih rendah dibandingkan dengan nilai rata-rata membuktikan adanya variasi yang rendah antara nilai maksimum dan minimum.

Nilai terendah variabel likuiditas diperoleh dari perusahaan Intikeramik Alamasri Industri Tbk (IKAI) pada triwulan 2 tahun 2019 sebesar 10,25. Nilai tertinggi diperoleh dari perusahaan Indonesian Paradise Property Tbk (INPP) triwulan 3 tahun 2019 sebesar 325,45. Nilai rata-rata likuiditas sebesar 131,494 yang berarti nilai rata-rata likuiditas pada sampel amatan yang digunakan dalam penelitian ini sejumlah 131,494. Nilai standar deviasi dari likuiditas adalah sebesar 73,125 yang menunjukkan bahwa sebesar 73,125 data bervariasi dari rata-rata. Nilai standar deviasi yang lebih rendah dibandingkan dengan nilai rata-rata membuktikan adanya variasi yang rendah antara nilai maksimum dan minimum.

Penelitian juga telah menguji normalitas data yang menunjukan nilai residual data penelitian ini berdistribusi normal. Penelitian ini juga melakukan uji asumsi klasik yaitu uji autokorelasi yang hasil ujinya menunjukan tidak ada gejala autokorelasi. Uji Multikolineritas menunjukan tidak terjadi multikolinieritas antar variabel dalam model regresi. Uji Heteroskendastisitas tidak ada gejala heteroskendastisitas, sehingga dapat disimpulkan bahwa data penelitian bebas dan memenuhi uji asumsi klasik. Selanjutnya hasil pengujian kelayakan model dijelaskan pada Tabel 3. 
Tabel 3. Hasil Uji Kelayakan Model (Uji F)

\begin{tabular}{|c|c|c|c|c|c|c|}
\hline Model & & $\begin{array}{l}\text { Sum of } \\
\text { Squares }\end{array}$ & Df & Mean Square & $\mathrm{F}$ & Sig. \\
\hline \multirow[t]{3}{*}{1} & Regression & 0,789 & 7 & 0,113 & 4,309 & 0,000 \\
\hline & Residual & 3,347 & 128 & 0,026 & & \\
\hline & Total & 4,136 & 135 & & & \\
\hline
\end{tabular}

Sumber: Data Penelitian, 2021

Uji F dilakukan untuk mengetahui model yang digunakan bersifat layak digunakan atau tidak sebagai variabel penjelas atau predictor. Tabel 3, menjelaskan model regresi memiliki nilai $F_{\text {hitung }}$ sebesar 4,309. Jumlah data (n) dalam penelitian ini adalah 135 dan jumlah variabel (k) sebanyak 7 variabel. Berdasarkan Tabel 3, diperoleh nilai signifikansi sebesar 0,000 nilai ini lebih kecil dari 0,05, sehingga dapat disimpulkan bahwa model penelitian ini layak digunakan.

Tabel 4. Hasil Uji Koefisien Determinasi $\left(\mathbf{R}^{2}\right)$

\begin{tabular}{ccccc}
\hline Model & $\mathrm{R}$ & $\mathrm{R}$ Square & Adjusted $\mathrm{R}$ Square & Std. Error of the Estimate \\
\hline 1 & $0,437^{\mathrm{a}}$ & 0,191 & 0,146 & 0,16171 \\
\hline
\end{tabular}

Sumber: Data Penelitian, 2021

Berdasarkan hasil analisis yang disajikan pada Tabel 4, nilai dari adjusted $R$ Square dalam penelitian ini sebesar 0,191 yang bermakna bahwa 19,1 persen variasi dari variabel return saham dipengaruhi oleh variabel profitabilitas, leverage, likuiditas, perbedaan opini investor, interaksi profitabilitas dan perbedaan opini, interaksi leverage dan perbedaan opini, interaksi likuiditas dan perbedaan opini sedangkan sisanya sebesar 80,9 persen dipengaruhi oleh faktor lain yang tidak dimasukkan dalam model regresi penelitian ini. Hasil regresi linier berganda dapat dilihat pada Tabel 5 .

Tabel 5. Hasil Analisis Regresi Linier Berganda dan Moderasi

\begin{tabular}{lrrrrr}
\hline \multirow{2}{*}{ Model } & \multicolumn{2}{c}{$\begin{array}{l}\text { Unstandardized } \\
\text { Coefficients }\end{array}$} & $\begin{array}{c}\text { Standardized } \\
\text { Coefficients }\end{array}$ & & \\
\cline { 2 - 4 } & \multicolumn{1}{c}{ B } & Std. Error & Beta & \multicolumn{1}{c}{ T } & Sig. \\
\hline (Constant) & $-0,123$ & 0,055 & & $-2,248$ & 0,026 \\
Profitabilitas & 0,006 & 0,003 & 0,234 & 2,166 & 0,032 \\
Leverage & 0,000 & 0,000 & $-0,117$ & $-1,029$ & 0,305 \\
Likuiditas & 0,001 & 0,000 & 0,274 & 2,823 & 0,006 \\
Perbedaan opini & 0,002 & 0,002 & 0,225 & 0,844 & 0,400 \\
Profitxopini & $7,415 \mathrm{E}-6$ & 0,000 & 0,009 & 0,084 & 0,933 \\
Leveragexopini & $1,376 \mathrm{E}-5$ & 0,000 & 0,166 & 0,940 & 0,349 \\
Likuiditasxopini & $-9,951 \mathrm{E}-6$ & 0,000 & $-0,215$ & $-1,082$ & 0,282 \\
\hline
\end{tabular}

Sumber: Data Penelitian, 2021

Berdasarkan hasil analisis yang disajikan dalam Tabel 5, maka persamaan regresi linier berganda dan moderasi adalah sebagai berikut:

$Y=-0,123+0,006 X_{1}+0,000 X_{2}+0,001 X_{3}+0,002 X_{4}+7,415 E-6 X_{1} X_{4}+1,376 E-5 X_{2} X_{4}-$ $9,951 \mathrm{E}-6 \mathrm{X}_{3^{*}} \mathrm{X}_{4}+\varepsilon$

Persamaan regresi linier berganda tersebut menunjukkan arah masingmasing variabel bebas pada variabel terikat (return saham) dimana tanda positif menunjukkan pengaruh yang searah sedangkan pengaruh negatif menunjukkan pengaruh yang berlawanan.

Hasil uji t pada penelitian ini disajikan pada Tabel 5, menjelaskan hasil analisis regresi linear berganda dan moderasi. Berdasarkan hasil analisis, maka 
hasil pengujian masing-masing variabel bebas dapat dijelaskan sebagai berikut:

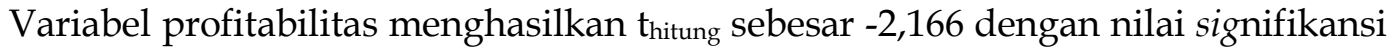
lebih lebih kecil dibandingkan 0,05, yaitu sebesar 0,032 (sig. $=0,032<0,05$ ) menunjukkan bahwa profitabilitas berpengaruh signifikan positif pada return saham. Hipotesis satu diterima.

Variabel leverage menghasilkan $t_{\text {hitung }}$ sebesar $-1,029$ dengan nilai signifikansi lebih besar dibandingkan 0,05, yaitu sebesar 0,305 (sig. $=0,305>0,05$ ) menunjukkan bahwa leverage tidak berpengaruh signifikan pada kinerja return saham. Hipotesis alternatif dua ditolak. Variabel likuiditas menghasilkan $t_{\text {hitung }}$ sebesar 2,823 dengan nilai signifikansi lebih besar dibandingkan 0,05, yaitu sebesar 0,006 (sig. $=0,006<0,05$ ) menunjukkan bahwa likuiditas berpengaruh positif signifikan terhadap kinerja return saham.

Variabel perbedaan opini investor menghasilkan $t_{\text {hitung }}$ sebesar 0,844 dengan nilai signifikansi lebih besar dibandingkan 0,05, yaitu sebesar 0,400 (sig. $=0,400>$ $0,05)$ menunjukkan bahwa perbedaan opini tidak berpengaruh signifikan pada kinerja return saham.Variabel moderasi profitabilitas dan perbedaan opini investor menghasilkan thitung sebesar 0,084 dengan nilai signifikansi lebih besar dibandingkan 0,05, yaitu sebesar 0,933 (sig. $=0,933>0,05$ ) menunjukkan bahwa moderasi profitabilitas dan perbedaan opini investor tidak berpengaruh signifikan pada kinerja return saham.

Variabel moderasi leverage dan perbedaan opini investor menghasilkan $t_{\text {hitung }}$ sebesar 0,940 dengan nilai signifikansi lebih besar dibandingkan 0,05, yaitu sebesar 0,349 (sig. $=0,349>0,05$ ) menunjukkan bahwa moderasi leverage dan perbedaan opini investor tidak berpengaruh signifikan pada kinerja return saham. Variabel moderasi likuiditas dan perbedaan opini investor menghasilkan $t_{\text {hitung }}$ sebesar 1,082 dengan nilai signifikansi lebih besar dibandingkan 0,05, yaitu sebesar 0,282 (sig. $=0,282>0,05)$ menunjukkan bahwa moderasi likuiditas dan perbedaan opini investor tidak berpengaruh signifikan pada kinerja return saham.

Profitabilitas berpengaruh positif dan signifikan pada return saham. Hasil penelitian ini menunjukkan bahwa apabila nilai profitabilitas meningkat maka return saham juga akan ikut meningkat. Hasil penelitian ini sesuai dengan teori keagenan dimana principal termotivasi mengadakan kontrak untuk mensejahterakan dirinya dengan profitabilitas yang selalu meningkat, dan agent termotivasi untuk memaksimalkan kebutuhan ekonomi dalam memperoleh investasi. Penelitian ini juga sesuai dengan teori sinyal berfungsi untuk memberikan kemudahan bagi investor untuk mengembangkan sahamnya yang dibutuhkan oleh manajemen perusahaan dalam menentukan prospek perusahaan di masa mendatang yakni salah satunya dengan profit/laba. Hasil penelitian ini sejalan dengan penelitian yang dilakukan oleh Mariani et al. (2016), Raningsih \& Putra (2015), Saleh (2015), Har \& Afif (2015), Allozi \& Obeidat (2016), dan Khan et al., (2013) menunjukkan bahwa profitabilitas berpengaruh positif dan signifikan terhadap return saham.

Pengujian penelitian tingkat nilai leverage mempunyai pengaruh positif pada kinerja return saham menunjukkan hasil leverage tidak signifikan pada return saham, yang dimana reaksi investor pada kondisi leverage meningkat tidak mempengaruhi keputusan investasi pada perusahaan sektor pariwisata. Hasil ini tidak terbukti kemungkinan karena perusahaan pariwisata di bursa tidak telalu 
diminati sebelum dan setelah krisis pandemi. Hasil ini tidak sejalan dengan teori sinyal yang menjelaskan bahwa sinyal leverage tidak memberikan sinyal positif dan tidak mempengaruhi nilai perusahaan.

Hasil penelitian tidak berpengaruh signifikan, bukan berarti investor bisa mengabaikan debt to equity ratio (DER) dalam suatu perusahaan, investor harus tetap memperhatikan DER karena adanya kondisi financial distress yang sering dihadapi oleh suatu perusahaan yang disebabkan karena kegagalan membayar kewajiban perusahaan (utang). Penelitian ini tidak mendukung teori keagenan yang menyatakan semakin tinggi leverage di dalam suatu perusahaan, maka semakin baik kemakmuran yang diterima pemegang saham perusahaan dari kreditur. Hasil penelitian ini sejalan dengan Allozi \& Obeidat (2016) dan Bararoh (2015) menunjukkan bahwa DER tidak berpengaruh terhadap return saham. Namun hasil penelitian ini bertolak belakang dengan penelitian yang dilakukan oleh Mariani et al., (2016), Raningsih \& Putra (2015), dan Abdullah et al., (2015) menunjukkan leverage berpengaruh positif dan signifikan terhadap return saham.

Likuiditas berpengaruh signifikan positif pada return saham, hal ini menunjukkan bahwa semakin tinggi likuiditas memengaruhi keputusan investor dalam berinvestasi di perusahaan sub sektor hotel, restoran, dan pariwisata. Penelitian ini sesuai dengan teori sinyal yang menyatakan bahwa semakin baik kinerja perusahaan seperti halnya rasio likuiditas dari laporan keuangan, menyebabkan semakin tertarik untuk menanamkan sahamnya. Hal tersebut sesuai karena nilai likuiditas (current ratio) mempengaruhi minat investor dalam menanamkan modalnya. Hasil penelitian ini sejalan penelitian yang dilakukan oleh Salamat \& Mustafa (2016) dan Parwati \& Sudiartha (2016) menemukan likuiditas berpengaruh berpengaruh positif dan signifikan terhadap return saham.

Hasil penelitian tidak membuktikan bahwa perbedaan opini investor berpangaruh terhadap kinerja harga saham. Hasil penelitian ini bertentangan dengan model Miller (1977) yang menjelaskan perbedaan opini investor berpengaruh terhadap return saham. Tidak membuktikan penelitian Houge et al (2001), Gao \& Zhong (2006) dan Jewarthowski \& Lizinska (2012) yang membuktikan secara empiris perbedaan opini investor berpengaruh negatif terhadap harga saham. Hasil penelitian tidak terbukti karena kemungkinan perdagangan saham pada perusahaan sektor pariwisata relatif sedikit dan cenderung tidak bergerak. Sampel penelitian menjelaskan sebagaian besar saham perusahaan ini kurang diminati oleh investor sehingga perdagangan sangat kecil dan jarang.

Hasil penelitian ini tidak membuktikan bahwa perbedaan opini investor memoderasi pengaruh profitabilitas terhadap kinerja harga saham. Hasil ini menjelaskan ketidaksepakatan investor terhadap pengumuman laba menyebabkan return saham menjadi lebih rendah pada saat pengumuman. Hasil penelitian ini mendukung penelitian Rice (2018), yang menjelaskan terdapat ketidakpastian dan perbedaan pendapatan investor dalam hal berita yang menimbulkan kekhawatiran tentang sesuatu termasuk profitabilitas yang menyebabkan investor merubah persepsinya sehingga mempengaruhi harga saham.

Hasil penelitian ini tidak dapat membuktikan moderasi perbedaan opini investor terhadap hubungan leverage dan kinerja harga. Perbedaan opini 
merupakan ketidaksepakatan keyakinan diantara investor terhadap harga saham (Doukas, et al, 2004). Perbedaan opini tidak memperkuat pengaruh leverage terhadap kinerja harga saham perusahaan sektor pariwisata karena hasil penelitian ini leverage memang tidak mempengaruhi kinerja harga saham sehingga perbedaan opini tidak mampu memperkuat dan mempengaruhi kinerja harga saham. Volume perdagangan yang menjadi dasar perbedaan opini tidak perbedaan volume perdagangan yang luar biasa pada saat terjadi pengumuman Covid-19 di Indonesia sehingga tentu saja perbedaan volume tidak banyak berubah.

Hasil penelitian ini tidak membuktikan moderasi perbedaan opini investor berpengaruh terhadap hubungan likuiditas dan kinerja harga saham. Perbedaan opini investor awal diduga dapat mengurangi pengaruh kinerja harga saham. Hasil penelitian tidak membuktikan karena informasi likuiditas tidak direspon oleh investor melalui peningkatan volume perdagangan saat pengumuman resmi Covid-19 di Indonesia. Perbedaan opini mengambarkan ketidaksepakatan penilaian investor terhadap informasi yang ditunjukan pada volume perdagangan (Houge, et al, 2001). Hasil penelitian ini tidak mendukung model Miller (1977) dan teori sinyal yang berhubungan dengan sinyal pengumumn Covid-19.

\section{SIMPULAN}

Berdasarkan hasil analisis dan pembahasan, maka dapat ditarik simpulan sebagai berikut: Profitabilitas berpengaruh positif dan signifikan pada return saham. Leverage yang tidak berpengaruh signifikan pada return saham berarti bahwa ada penilaian yang berbeda dari investor terhadap arti pentingnya hutang bagi perusahaan. Likuiditas berpengaruh signifikan positif pada return saham, hal ini menunjukkan bahwa semakin tinggi likuiditas memengaruhi keputusan investor dalam berinvestasi di perusahaan sub sektor hotel, restoran, dan pariwisata. Perbedaan opini investor dalam penelitian ini tidak berpengaruh signifikan pada kinerja return saham. Hasil penelitian ini juga tidak membuktikan bahwa perbedaan opini investor memoderasi pengaruh profitabilitas terhadap kinerja harga saham. Hasil penelitian ini tidak dapat membuktikan moderasi perbedaan opini investor terhadap hubungan leverage dan kinerja harga. Hasil penelitian ini juga tidak membuktikan moderasi perbedaan opini investor berpengaruh terhadap hubungan likuiditas dan kinerja harga saham. Perbedaan opini investor pada saat pandemi Covid-19 selama 2 periode tidak memberikan banyak reaksi pasar terutama pada perdagangan saham perusahaan pariwisata, kemungkinan karena perusahaan sektor pariwisata kurang diminati oleh investor sehingga perdagangan tidak banyak mengalami fluktuasi.

Investor yang ingin berinvestasi diharapkan untuk mempertimbangkan rasio keuangan dalam menilai dan memutuskan berinvestasi pada suatu perusahaan. Hasil penelitian perbedaan opini tidak terbukti berpengaruh terhadap kinerja harga saham pada perusahaan pariwisata kemungkinan karena perusahaan ini kurang diminati investor sehingga tidak terjadi fluktuasi perdagangan. Keterbatasan penelitian ini hanya menggunakan perusahaan sektor pariwisata dan tahun penelitian yang pendek, sehingga disarankan penelitian selanjutnya adalah menggunakan sektor perbankan atau manufaktur karena 
kedua sektor ini cukup berdampak dan harga sahamnya pada saat pandemi berfluktuasi.

\section{REFERENSI}

Abdullah, MN., Kamrudin, P., Tarana K., \& Rahat, BT. (2015). The Impact of Financial Leverage and Market Size On Stock Returns On The Dhaka Stock Exchange: Evidence From Selected Stocks In The Manufacturing Sector. International Journal of Economics, Finance and Management Sciences, 3(1), pp.1015.

Acheampong, P., Agalega, E., \& Shibu, A. K. (2014). The Effect of Financial Leverage and Market Size on Stock Returns on the Ghana Stock Exchange: Evidence from Selected Stocks in the Manufacturing Sector. International Journal of Financial Research, 5(1), pp. 125-134. https://doi.org/10.5430/ijfr.v5n1p125

Allozi, N. M., \& Obeidat, G. S. (2016). The Relationship between the Stock Return and Financial Indicators (Profitability, Leverage): An Empirical Study on Manufacturing Companies Listed in Amman Stock Exchange. Journal of Social Sciences (COESERJ-JSS), 5(3), pp. 408-424. https://doi.org/10.25255/jss.2016.5.3.408.424

Araújo, R.C.C., \& Machado, M.A.V. (2018). Book-to-Market Ratio, return on equity and Brazilian Stock Returns. RAUSP Management Journal, 53(3), pp. 324-344. https://doi.org/10.1108/RAUSP-04-2018-001

Bararoh, Tantri. (2015). Analysis of Fundamental Factors, Foreign Exchange and Interest Rate on Stock Return (Studies in Manufacturing Companies Listed on Indonesia Stock Exchange for 2011-2013 periods). International Journal of Business and Management Invention, 4(2), pp.36-42.

Brigham, E. F., \& Houston. (2010). Dasar-dasar Manajemen Keuangan. Jakarta: Salemba Empat.

Fahmi et al. (2019). Pengaruh Profitabilitas dan Rasio leverage terhadap Return Saham pada Perusahaan BUMN yang terdaftar di Indeks LQ45. Jurnal Ilmiah Mahasiswa Ekonomi Manajemen Universitas Singaperbangsa Karawang, 4(3), hal. 509-518.

Gao, Y dan Zhong, M (2006) Divergence of opinion and long term performance of intial public offering. Journal of financial research 29.

Ghozali, Iman (2020) 25 Grand Theory. Yoga Pratama. Semarang

Har, Wong Pik and Muhammad Affi. (2015). The Impact of Accounting Earning on Stock Return: The Case of Malaysia's Plantation Industry. International Journal of Business and Management, 10(4), pp.155-165.

Houge T Loughran T Suckanek dan Yan X (2001) Divergen opinion uncertainty and the quality of initial public offering, Financial management.

Indrawati, S.M. (2020). Pemerintah Waspada Dampak Pandemi Covid-19 Terhadap Ekonomi Indonesia. Diunduh dari Kemenkeu.com website: https://www.kemenkeu.go.id/media/15072/sp-27-pemerintah-waspadadampak-pandemi-Covid-19-terhadap-ekonomi-indonesia.pdf

Jensen \& Meckling. (1976). The Theory of The Firms Manajerial Behaviour, Agency Cost, and Ownership Structure. Journal of Financial and Economics, 3, pp. 305360.

Jewwartowski dan Lizinska (2012) Short and long term performance of polish 
IPOs. Emergency markets finance $\mathcal{E}$ trade 48

Khan, M.K. et al. (2017). Nexuses between Economic Factors and Stock Returns in China. International Journal of Economics and Finance, 9(9), pp. 182-191. doi: 10.5539/ijef.v9n9p182

Mariani, N. L. L., Yudiaatmaja, F., \& Yulianthini, N. N. (2016). Pengaruh Profitabilitas dan Leverage terhadap Return Saham. E-Journal Bisma Universitas Pendidikan Ganesha, 4. https:// doi.org/10.1097/BRS.0000000000000512

Miller, E.M (1977) Risk, uncertainty and divergen of opinion. The Journal of finance 32.

Nurhakim S, Anistia; Irni Yunita, and Aldilla Iradianty. (2016). The Effect of Profitability and Inflation on Stock Return at Pharmaceutical Industries at BEI In the Period of 2011-2014. Asia Pasific Jornal of Advanced Business and Sosial Studies, 2(2), pp.202-210.

Parwati, R. R. D., \& Sudiartha, G. M. (2016). Pengaruh Profitabilitas, Leverage, Likuiditas Dan Penilaian Pasar Tehadap Return Saham Perusahaan Manufaktur. E-Jurnal Manajemen Universitas Udayana, 5(1), hal. 385-413.

Raningsih, N. K., \& Putra, I. M. P. D. (2015). Pengaruh Rasio-Rasio Keuangan dan Ukuran Perusahaan pada Return Saham. E-Jurnal Akuntansi, 13(2), hal. 582598. https://ojs.unud.ac.id/index.php/Akuntansi/article/view/12325/11032

Salamat, W. A. Al, \& Mustafa, H. H. H. (2016). The Impact of Capital Structure on Stock Return : Empirical Evidence from Amman Stock Exchange. International Journal of Business and Social Science, 7(9), pp. 183-196. https://doi.org/https://doi.org/10.33094/7.2017.2019.51.9.21

Saleh, Muhammad. (2015). Relationship between Firm's Financial Performance and Stock Return: Evidence form Oil and Gas Sector Pakistan. Jornal of Energy Technologies and Policy, 5(10), pp.27-32.

Sawir, Agnes. (2010). Analisa Kinerja Keuangan dan Perencanaan Keuangan Perusahaan. Jakarta: PT Gramedia Pustaka Utama.

Sugianto, Danang, (2020) https:/ / finance.detik.com/bursa-dan-valas/d4972595/ perjalanan-ihsg-sejak-ri-positif-virus-corona 